\section{The Impact of Economic and Financial Management Practices on the Performance of Mexican Micro-Enterprises: A Multivariate Analysis}

\author{
Martín Ramírez-Urquidy ${ }^{1}$ \\ José G. Aguilar-Barceló ${ }^{1}$ \\ ${ }^{1}$ Universidad Autónoma de Baja California, School of \\ Economics and International Relations, Tijuana, México \\ Malena Portal-Boza ${ }^{2}$ \\ ${ }^{2}$ Universidad Autónoma de Baja California, School of \\ Accounting and Management, Tijuana, México
}

\begin{abstract}
Purpose - The goal of this paper is to characterize the economic and financial management (EFM) practices in Mexican micro-enterprises and determine their impact on business performance under the hypothesis that EFM practices focused on achieving the optimal level of liquidity and profitability positively affect the performance of micro-enterprises.
\end{abstract}

Design/methodology/approach - The study applies factor analysis, including both exploratory and confirmatory techniques, as well as linear regression models.

Findings - The econometric analysis shows that both economic and financial management are statistically significant in explaining microenterprise performance, although only the effect of the latter is positive, whereas that of the former is negative.

Originality/value - The paper's findings could guide training and microcredit programs focused on micro-enterprise owners in developing countries and help to improve decision-making processes.

Keywords - micro-enterprises, economic management, financial management.

\section{Received on}

12/05/2016

Approved on

03/14/2018

\section{Responsible editor:}

Prof. Dr. Eduardo Contani

Prof. Dr. Joao Mauricio Gama

Boaventura

\section{Evaluation process:}

Double Blind Review

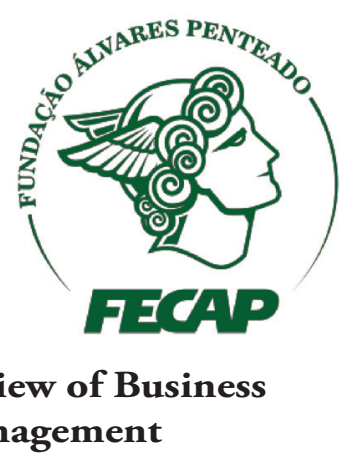

DOI: $10.7819 /$ rbgn.v20i3.3518 


\section{Introduction}

One of the main explanations for the diversity of entrepreneurship patterns across countries is their level of economic development (Acs \& Amorós, 2008). Thus, Latin American countries, which face development challenges, display a corresponding business structure that is biased toward micro-enterprises. This is also the case for Mexico, where micro-enterprises represent the vast majority of businesses according to Economic Census data: on average, $95.4 \%$ of established businesses and $97.3 \%$ new start-ups are micro-enterprises, employing $39.7 \%$ of the total workforce.

Despite efforts to provide technical and financial assistance to micro-enterprises through government and non-government business development programs, many business management problems such as debt, liquidity, and profitability still persist, which threaten business growth and survival (Mungaray \& Ramírez, 2000). Moreover, the lack of managerial and financial controls and deficient planning - among others - associated with economic and financial management (EFM) are the main factors leading these businesses to failure (Rodríguez, 2010).

Empirical studies related to the economic and financial dimensions of management applied to Latin American countries include the analysis of financial problems and liquidity constraints (León \& Schreiner, 1998), the development of models to measure economic performance in small and medium enterprises (Escobar, Arias, \& Portilla, 2009), and research on strategic operational planning (Sierra \& Madriz, 2012; Velásquez, 2003). These studies have contributed to the subject of EFM in micro-enterprises, filling some of the gaps in economic and financial management. The goal of this paper is to characterize the EFM practices in Mexican micro-enterprises and determine their impact on business performance under the hypothesis that EFM practices focused on achieving the optimal level of liquidity and profitability positively affect the performance of micro-enterprises.
The study applies factor analysis, including both exploratory and confirmatory techniques, as well as linear regression models to determine the impact of the main EFM factors on business performance. The data was obtained from the Mexican National Micro-Enterprise Survey (ENAMIN) (INEGI, 2012). The econometric analysis shows that both economic and financial management are statistically significant in explaining micro-enterprise performance, although only the effect of the latter is positive, whereas that of the former is negative. The paper's findings could guide training programs focused on micro-enterprise owners in developing countries and should enrich the stock of literature on microenterprises, which may support further research.

\section{The Role of EFM in Micro- Enterprise Performance}

The goal of the economic management of enterprises is to achieve profitability, and that of financial management is to obtain sufficient liquidity to fulfill short-term liabilities and develop residual business opportunities. Therefore, the essential functions of the management of successful organizations are economic and financial in nature, and are achieved by controlling the key variables affecting the organization. At the same time, economic management is responsible for carrying out the activities of an organization efficiently and effectively, thus ensuring expected results. In relation to this, Drucker (1973) states that efficiency is the key to the success of an organization: "Before we dedicate ourselves to doing something efficiently, we have to be sure that we have found something right to do".

Profitability, according to Gitman and Zutter (2012), is the result of the relationship between income and expenses generated by the use of the organization's assets in production. It may be considered as a short-term goal required for healthy performance, where all the material, human, and financial resources are combined and mobilized. Accordingly, profitability may also be considered as one of the goals of micro-enterprises, 
toward which a combination of planning and control activities should be directed, not only to manage the required economic resources, but also to guarantee that these resources generate the expected returns on investment.

Stoner, Freeman, \& Gilbert (1996) define planning as a process of setting goals and determining the means to achieve such goals. Planning, according to Anzola (2002), covers all the departments of an enterprise and contributes to answering questions such as what and how to produce, how to distribute products to customers, how to keep accounting records, what prices to set, or what sales strategies to implement. Therefore, planning is crucial to achieving an efficient organization of resources, reducing the costs arising from uncertainty and constant change, and maximizing the potential effects of economic management.

Economic management includes the control of essential resources. The purpose of controls is to achieve results that are consistent with the organization's objectives. There are economic controls to make sure that transactions are registered meticulously, ensuring that the employees are unable to disrupt the management system. On the other hand, controls can also help the decision-making process through more accurate financial projections. Good decisionmaking requires reliable accounting records that provide basic information that reflects all the commercial, financial, and fiscal transactions executed over a period of time. The execution of these controls will contribute to generating positive profits, thus increasing the likelihood of the organization's survival.

Economic management cannot be separated from financial management. Paramasivan and Subramanian (2009) suggest that financial management is the application of the general principles of management for financial decision-making and the execution of certain practices for the effective procurement and application of the funds required for the business to operate. Brealey, Myers, and Allen (2008) claim that financial managers face two problems: first, deciding how much and in which assets to invest; second, deciding how to raise the necessary funds to make such investments. The common element in these perspectives is that financial management refers to investment and financing decisions as the leading elements, including the selection of funding sources.

Thus, EFM can be defined as a set of processes concerned with planning, procuring, and controlling economic and financial resources, which implies timely decisions to achieve the required profitability and liquidity for a healthy business operation. Therefore, strengthening EFM dynamics is required to ensure the sustainability and survival of businesses in the context of strong market competition.

It is important to highlight that although most of the micro-enterprises in less developed niche markets operate with reduced capital, they can still benefit from performing EFM activities, e.g. accounting procedures, such as keeping records of operations, establishing controls, and generating basic information for the decisionmaking process. In addition, micro-enterprises are required to carry out a series of short-term actions to seek efficiency and differentiation from the competition to guarantee a required level of production and sales, as well as to maintain or increase their customer base. These strategies will impact the performance of micro-enterprises, as has been analyzed by some authors, such as Quinn and Rohrbaugh (1983), Benett, Ketchen, and Schultz (1998), Hill and Jones (2005), Hitt, Ireland, and Hoskisson (2008), and Porter (1980), who suggests that some competitive factors may increase firm value and profitability, and improve outcomes.

Within the financial dimension, meeting the asset investment requirements of microentrepreneurs, such as in equipment, tools, machinery, or commercial properties, among others, is critical to supporting business endurance. However, it is not enough to simply identify the investment needs; it also requires deciding the 
amount of investment, and the financing source and cost. Interest rates are of particular importance and must be taken into account since they could be excessively high for the micro-entrepreneur's income, thus affecting profitability and business survival.

Most of the empirical studies referring to the EFM in micro-enterprises focus on liquidity constraints; others focus on financing issues (León \& Schreiner, 1998). For example, Correa and Jaramillo (2007) address financial management in small businesses in Colombia by outlining guidelines for the development of this process and tools for planning, controlling, and financial decision-making. Also for Colombia, Escobar et al. (2009) recommend the use of models to measure the financial situation of small and medium enterprises; Mariño and Medina (2009) analyze the gap between theory and practice for financial management in the wholesale business and automotive and manufacturing sectors in this country. Some interesting results were found in this research: e.g. $47.8 \%$ of micro, small, and medium enterprises do not use financial instruments for decision-making, arguing that they do not have the knowledge or that these practices are not important for their enterprises. Also, 45\% of the businesses keep accounting records and issue sales and purchase invoices, while only $2 \%$ have accounting software. Finally, for Venezuela, Vera-Colina (2011) introduces a tool to evaluate financial management practices in small and medium enterprises. This tool consists of a survey for the diagnosis of financial management based on a non-experimental, crosssectional, and correlational field design, which includes 62 items with scale-type responses, with an interval measurement and score scale.

The literature provides some evidence regarding the use of economic and financial management practices in Mexican microenterprises. For instance, Red PYMES-Cumex (2010) elaborated a comparative study about the financial and managerial profile of small businesses in five of the 32 Mexican states; and Ramírez, Mungaray, and Guzmán (2009) found that micro-enterprises seek informal or less regulated financing sources when they face liquidity problems. In addition, Aguilar, Ramírez, and Barrón (2007) suggest possible relationships between some of the following components of EFM in micro-enterprises at the northern border of Mexico: credit conditions and the type of accounting applied, stock and sales control systems, and financing requirements and the type of suppliers. The authors find that there is a relationship between supplier credit and the type of accounting used. They also suggest that those micro-entrepreneurs exhibiting some kind of accounting or bookkeeping background also display a higher chance of accessing supplier credit, which is important for micro-enterprises to improve operations and profitability. They also find a relationship between planning purchases from suppliers, stock control, and sales, and a link between required financing and the type and volume of purchases made by the microenterprises.

Mungaray et al. (2007) evaluated the economic and financial performance of microenterprises in northwestern Mexico. They showed that it is possible to analyze micro-enterprises using the traditional methods and techniques of project economic evaluation by performing a series of adaptations. They also observed that business owners are often unaware of the existing and potential profitability of their businesses and face a lack of information and advice that would allow them to know their business investment needs or their opportunity costs derived from other market segments.

More recently, O'Neill, Sohal, and Teng (2016) demonstrated that a quality management orientation (including the use of financial and productivity ratios as performance measures) provides a statistically significant survival and financial performance advantage in the small firms sector. In addition, Pollack and Adler (2016) showed that project management and information skills represent a significant and positive influence 
on sales and profitability in small and medium enterprises. Thus, these practices are related to performance.

\section{Methodology and Data Sources}

\section{I Empirical approach}

The empirical work is performed using factor and regression analysis. The former is carried out in order to group the most relevant EFM variables, discriminating them from the whole data set. The latter is performed in order to measure the relationship of the EFM variables with micro-enterprise performance variables in order to determine the effect of EMF practices.

Factor analysis is a multivariate statistical technique that synthesizes, in a concise and reliable manner, the observed interrelationships between a set of variables (Méndez \& Rondón, 2012). The interrelated variables are known as factors. An exploratory factor analysis is first conducted due to the lack of a theoretical model, and then confirmatory factorial analysis is carried out, which is derived from the former. The outcome of this procedure will be a structure composed of factors, that is, a set of variables representing the EFM elements. Through the confirmatory analysis, the number of factors and their weights will be confirmed, providing the set of variables that will be included as regressors in the linear regression model.

Factor analysis starts with formulating the problem, explained by a set of variables $X_{1}, X_{2}, X_{3}$, $\ldots, X_{p}$; the variables are measured in $p$ individuals. This can be represented as the following equation system:

$$
\begin{aligned}
& X_{1}=\alpha_{11} F_{1}+\alpha_{12} F_{2}+\ldots+\alpha_{1 k} F_{k}+u_{1} \\
& X_{2}=\alpha_{21} F_{1}+\alpha_{22} F_{2}+\ldots+\alpha_{2 k} F_{k}+u_{2} \\
& X_{p}=\alpha_{p 1} F_{1}+\alpha_{p 2} F_{2}+\ldots+\alpha_{p k} F_{k}+u_{p}
\end{aligned}
$$

where $F_{1}, \ldots, F_{k}(k<<p)$ are the common factors, $u_{p}, \ldots u_{p}$ are the unique or specific factors, and the coefficients $\left\{\alpha_{i j} ; i=1, \ldots p ; j=1, \ldots, k\right\}$ are the factor loadings. It is assumed that the common factors are standardized $\left(E\left(F_{i}\right)=0\right.$; $\left.\operatorname{var}\left(F_{i}\right)=1\right)$, that the specific factors have a mean equal to zero and are uncorrelated $\left(E\left(u_{i}\right)=O\right.$; $\operatorname{cov}\left(u_{i}, u_{j}\right)$ $=0$ if $i \neq j ; i, j=1, \ldots, p)$, and that both types of factors are also uncorrelated $\left(\operatorname{cov}\left(F_{i}, u_{j}\right)=0, \forall i\right.$ $=1, \ldots, k ; j=1, \ldots, p)$.

By using these assumptions, it follows that:

$$
\operatorname{var}\left(X_{i}\right)=\sum_{j=1}^{k} \alpha_{i j}^{2}+\Psi_{i}=h_{i}^{2}+\Psi_{i}
$$

where $h_{i}^{2}=\operatorname{var}\left[\sum_{j=1}^{k} \alpha_{i j} F_{j}\right]$ e $\Psi_{i}=\operatorname{var}\left(u_{i}\right)$ and are the commonality and specificity of the variable $X_{i}$ for $i=1, \ldots, p$, respectively. Therefore, the variance of each variable can be segregated into two parts: one, the commonality $\left(h_{1}^{2}\right)$, which represents the proportion of the total variance shared by two or more factors or the variance of the common factors; and two, specificity $\left(\Psi_{i}\right)$, which represents the part of the variance due to factors specific to each variable. Also, the following formulation must be taken into account:

$$
\operatorname{cov}\left(x_{i}, x_{\ell}\right)=\operatorname{cov}\left[\sum_{j=1}^{k} \alpha_{i j} F_{j}, \sum_{j=1}^{k} \alpha_{\ell j} F_{j}\right]=\sum_{j=1}^{k} \alpha_{i j} \alpha_{\ell j}
$$

Therefore, common factors explain the existing relationships between the variables under analysis, and are subjected to experimental interpretation. The unique factors are included in the regression models, because of the impossibility of expressing variables as a function of a lesser number of factors.
The relationship between the EFM factors and micro-enterprise performance is measured by estimating a Cobb-Douglas production function, which outlines the relationship between the outputs and combinations of inputs. The CobbDouglas production function is widely used in the literature to represent production structures 
and productivity performance at a firm level or even in larger aggregations. The basic formulation of this function suggests that output is explained by two essential factors, e.g. capital and labor. However, it allows the inclusion of more variables in order to assess their contribution to productive performance, such as control variables or qualitative variables. This possibility might provide clues about the contribution of variables such as those related to EFM.

The estimation of the production function is based on the following model:

$$
Y_{i}=F\left[\mathrm{e}^{\alpha(g e, g f, z)}, \beta_{1}, \beta_{2}, K_{i}, L_{i}\right]
$$

In this mathematical expression, $Y_{i}$ is output and the parameter $\alpha(g e, g f, z)$ is the constant or the intercept of the regression. The variables $K_{i}$ and $L_{i}$ represent capital and labor, which are associated with the coefficients $\beta_{1}$ and $\beta_{2}$, respectively. The regression constant includes the economic dimension ( $g e$ ) and the financial dimension $(g f)$, both included as EFM practices, as well as other control variables explicitly considered in the model $(z)$. Dimensions and are derived from the factor analysis, as explained before. Equation (6) assumes that capital and labor are essential, such that if they equal zero, production will also be zero, while the EFM elements are associated with the efficiency of the use of productive factors and management, affecting total factor productivity. This assumption suggests that EFM practices should affect the overall productivity of an organization (e.g. micro-enterprises), which is to be measured by the empirical models.

In order to empirically estimate equation 6 , it should be transformed by applying the natural $\log$ of the equation, as shown in equation 7 :

$$
\operatorname{Ln} Y_{i}=\alpha+\alpha_{g e}+\alpha_{g f}+\alpha_{z}+\beta_{1} \operatorname{Ln} K_{i}+\beta_{2} \operatorname{Ln} L_{i}
$$

where $\beta_{1}$ and $\beta_{2}$ are transformed into the output elasticity of capital and the output elasticity of labor, which indicate the percentage change of output given a $1 \%$ change in capital and labor, respectively. The $\alpha$ parameters may be considered as the part of output not depending on factors, but on the variable associated with EFM and other control variables represented by $\mathrm{z}$.

Regression 7 is estimated for Manufacturing, Commerce, and Services, and also for all of the three sectors together, in a regression labeled as the consolidated regression.

\subsection{Variables}

The data was obtained from the Mexican National Micro-Enterprise Survey (ENAMIN) and was collected by INEGI during the fourth quarter of 2012 (INEGI, 2012). The ENAMIN is a national representative survey taken from a subsample of all available small business owners included in the National Occupation and Employment Survey (ENOE). This survey includes information on self-employed workers and microenterprises operating in the manufacturing, extraction, construction, transport, commerce, and service sectors. It provides detailed firmlevel data on productive resources, organization, and amount and distribution of expenditure and income, among others. The businesses in the survey have between 0 and 15 employees if involved in manufacturing and between 0 and 10 employees if they are part of the commerce or service sector.

In accordance with the literature, variables representing the EFM factors, such as bookkeeping system, planning, and some economic controls (Table 1), were identified from survey questions. The selected questions were the following: a) How do you carry out the bookkeeping activity in your micro-enterprise? b) How are sales registered and revenue recognized? c) How are the prices of products/ services set? and d) Is the micro-enterprise recognized by the authorities or official agencies (is it formal)? Data from these questions were transformed into 
independent variables to represent economic management $(g e)$.

To represent the financial management (gf) of the micro-enterprises (e.g. that related to investment and finance decisions), the independent variables were taken from the following questions: a) What was the funding source for the startup? b) How much did you invest in your micro-enterprise last year? c) In which business area was the investment made? and d) Ifyou used a loan, what was the cost of it?

Table 1

Proxy variables for EFM proposed by authors

\begin{tabular}{|c|c|c|}
\hline Type of Variable & Question from survey & Proposing authors \\
\hline $\begin{array}{l}\text { Economic } \\
\text { management }\end{array}$ & $\begin{array}{l}\text { a) How do you carry out the bookkeeping activity in your micro- } \\
\text { enterprise? } \\
\text { b) How are sales registered and revenue recognized? } \\
\text { c) How are the prices of products/services set? } \\
\text { d) Is the micro-enterprise recognized by the authorities or official } \\
\text { agencies (is it formal)? }\end{array}$ & $\begin{array}{l}\text { Aguilar et al. (2007) } \\
\text { Mariño and Medina (2009) } \\
\text { Ramírez et al. (2009) }\end{array}$ \\
\hline Financial management & $\begin{array}{l}\text { a) What was the funding source for the start-up? } \\
\text { b) How much did you invest in your micro-enterprise last year? } \\
\text { c) In which business area was the investment made? } \\
\text { d) If you used a loan, what was the cost of it? }\end{array}$ & $\begin{array}{l}\text { Paramasivan and Subramanian (2009) } \\
\text { Brealey et al. (2008) } \\
\text { Ramírez et al. (2009) } \\
\text { Aguilar et al. (2007) } \\
\text { Jaramillo (2007) }\end{array}$ \\
\hline
\end{tabular}

The dependent variable $Y_{i}$, representing business performance, was obtained from the following question: What is your monthly income? This variable is the result of the ability of the enterprise to raise funds and combine inputs so as to accomplish the organization's goals, e.g. achieving a certain level of income. In addition, inputs were incorporated into the analysis, such as the average weekly man-hours worked $\left(L_{i}\right.$ ), and the value of the assets, as a proxy for the productive capital stock $\left(K_{i}\right)$. The selection of the average weekly man-hours worked is the most common labor variable used in production function analysis as it is more accurate than just using the number of workers. The construction of this variable is simply the result of the number of workers multiplied by the average working hours over a week. As for the capital variable, the value of the assets is also standard in production analysis, given the complication of including physical and standard measures of capital that are comparable between micro-enterprises. Thus, the most common measure is the value of assets per micro-enterprise, which is provided by the data source directly. A similar argument applies for the selection of monthly income, which is also provided in money measures for comparability purposes, since output units differ greatly between micro-enterprises, as they produce different products.

Finally, other control variables were included and grouped in, such as sex of the entrepreneur and sector, whether commerce, services, or manufacturing. The inclusion of these controls is recognition of potentially great differences between the micro-enterprises across sectors, in terms of sector dynamics, value added, competition trends, institutional factors affecting each sector, and other unknown factors. The inclusion of the gender dichotomy is justified by the well-known entrepreneur pattern differentials between being males and females: female entrepreneurs tend to be part time, splitting domestic and business activities between the enterprise and the household, and are motivated by a need to complement household income; male entrepreneurs tend to be full time and generate enterprises that tend to be the core incomegenerating activity in the household (Mungaray \& Ramirez-Urquidy, 2011). Thus, accounting for such differences may correct the empirical model. 


\subsection{Description of economic and financial management data}

After filtering the data, the number of valid observations is 3,275 micro-enterprises: 569 operating in manufacturing, 1,086 in commerce, and 1,620 in services. According to the descriptive statistics, only a small part of the micro-enterprises keeps accounting records: $62 \%$ in manufacturing, $44 \%$ in commerce, and $56 \%$ in services; about $21 \%$ of the micro-enterprises in manufacturing and $22 \%$ in commerce and services employ an accountant or a professional to keep accounting records. Also, $15 \%$ of the businesses in manufacturing, $26 \%$ in commerce, and $18 \%$ in services employ a personal, nonprofessional system to keep accounting records; between $2 \%$ and $7 \%$ of micro-entrepreneurs in these sectors use the cash register provided by the tax authority.

Approximately $75 \%$ of the microenterprises in all the economic sectors do not issue any kind of sales receipts or proof of purchase. In manufacturing, $12 \%$ use invoices and $12 \%$ use delivery notes; in commerce this is $9 \%$ and $15 \%$, and in the service sector it is $14 \%$ and $12 \%$, respectively. This data suggests that micro-enterprises do not usually keep accounting records, nor use any type of proof of purchase in their sales. This is in fact an important deficiency for the decision-making process, which may be limiting the profitability of micro-enterprises.

With regard to pricing, the most important practice in these micro-enterprises is adding a margin to the cost: this accounts for $40 \%$ in manufacturing, $43 \%$ in commerce, and $44 \%$ in the service sector; in general, $44 \%$ of the micro-enterprises set prices in accordance with competitors. In relation to financial management, the observed behavior in the manufacturing and services sectors is that $40 \%$ and $34 \%$ of the micro-enterprises, respectively, do not invest in assets. The percentage is significantly different for commerce, since 55\% do not engage in investment activities. The most common financing source was commercial banks, accounting for $38 \%$ in manufacturing, $41 \%$ in commerce, and $41 \%$ in services; the second most widely-used financing source was credit unions, accounting for $28 \%$, $26 \%$, and $25 \%$ in these sectors, respectively.

The average amount of loans is 3,300 dollars in manufacturing, 2,260 dollars in commerce, and 1,730 dollars in services; however, the most frequent loan amount in all three sectors is 330 dollars, which is undoubtedly associated with liquidity issues. Regarding loan duration, in $50 \%$ of the micro-enterprises it is one year or less to pay back the loan. Most of the micro-enterprises use the loans to invest in working capital, particularly in the acquisition of inputs. This is true for $64 \%$ of the businesses in manufacturing, $86 \%$ in commerce, and $39 \%$ in services. Particularly in the commerce sector, other loan purposes were mentioned, such as acquiring fixed assets, i.e. commercial properties, vehicles, and fixing and maintaining machinery and tools, which are important for business continuity.

Although some micro-enterprises make subsequent investments through external financing, many of them use personal savings to start up the business. According to Kantis et al. (2002), micro-entrepreneurs mention personal savings as the most used financing source (85\%), followed by soft loans from relatives and friends (25\%), and only $20 \%$ mention bank loans. Public institutions are used in just over $2 \%$ of the cases. This data may reflect the fact that about $90 \%$ of the businesses are not officially registered; that is, they operate informally.

\section{Empirical Results and Discussion}

By checking the results of the correlation matrix test, it was confirmed that the data meets the necessary requirements to be used in factor analysis. The Kaiser-Meyer-Olkin measure of sampling adequacy (which was between 0.583 and 0.637 in all cases) and Bartlett's sphericity test (which showed a level below the critical 0.05 threshold in all cases) indicate that the data falls within acceptable ranges for the application of the model and that a sufficient correlation exists between the variables. 
The factor matrix estimation was used to calculate the weights of each variable in terms of its correlation with each factor (Table 2). Afterwards, we obtained a new factor loading matrix through a factor rotation process. Once the rotation was performed, the weights were evaluated to identify the most representative variables, which are to be included in the regression analysis.

Table 2

Rotated component matrix by sector

\begin{tabular}{|c|c|c|c|c|c|c|c|c|c|c|c|c|}
\hline \multirow{3}{*}{ Variables } & \multicolumn{12}{|c|}{ Components } \\
\hline & \multicolumn{4}{|c|}{ Manufacturing sector } & \multicolumn{4}{|c|}{ Commerce sector } & \multicolumn{4}{|c|}{ Service sector } \\
\hline & 1 & 2 & 3 & 4 & 1 & 2 & 3 & 4 & 1 & 2 & 3 & 4 \\
\hline Accounting records & .882 & & & & & .867 & & & & .883 & & \\
\hline Sales receipts & .878 & & & & -.306 & .783 & & & & .878 & & \\
\hline How are the prices set? & & & & .825 & & & & 999 & & & & .998 \\
\hline Investment amount & -.504 & & .453 & & & & & & .866 & & & \\
\hline Financing sources & & .742 & & & & & .773 & & & & .710 & \\
\hline Who was the lender? & & .597 & & & & & .728 & & & & .799 & \\
\hline Loan amounts & & & & & .871 & & & & .870 & & & \\
\hline Monthly financing cost & & & .873 & & .879 & & & & .523 & & & \\
\hline How is the loan used? & & .481 & & -.564 & & & & & & & & \\
\hline
\end{tabular}

The evidence suggests four factors for each of the three economic sectors and for the consolidated case (the result of adding all three sectors), and includes a set of variables selected

Table 3

Factors and variables by economic sector from the exploratory analysis based on the literature (see Table 3). It should be noted that the variables are binary and ordinal.

\begin{tabular}{|c|c|c|c|c|}
\hline \multirow{2}{*}{ Factors } & \multicolumn{4}{|c|}{ Variables included in... } \\
\hline & Manufacturing & Commerce & Services & Consolidated \\
\hline Factor 1 & $\begin{array}{l}\text { Economic management } \\
\text { (recording and control). } \\
\text { Use of accounting records. } \\
\text { Issuing of sales receipts. }\end{array}$ & $\begin{array}{l}\text { Financial management } \\
\text { (financing sources and } \\
\text { investment decisions). } \\
\text { Monthly financing cost. } \\
\text { Loan amounts. } \\
\text { How is the loan used? }\end{array}$ & $\begin{array}{l}\text { Financial management (financing } \\
\text { sources and investment } \\
\text { decisions). } \\
\text { Investment amount. } \\
\text { Monthly financing cost. } \\
\text { Loan amounts. } \\
\text { How is the loan used? }\end{array}$ & $\begin{array}{l}\text { Economic management } \\
\text { (recording and control). } \\
\text { Use of accounting records. } \\
\text { Issuing of sales receipts. }\end{array}$ \\
\hline Factor 2 & $\begin{array}{l}\text { Financial management } \\
\text { (financing sources and } \\
\text { investment decisions). } \\
\text { Financing for the start-up. } \\
\text { Financing sources. } \\
\text { Who was the lender? }\end{array}$ & $\begin{array}{l}\text { Economic management } \\
\text { (recording and control). } \\
\text { Use of accounting records. } \\
\text { Issuing of sales receipts. }\end{array}$ & $\begin{array}{l}\text { Economic management } \\
\text { (recording and control). } \\
\text { Use of accounting records. } \\
\text { Issuing of sales receipts. }\end{array}$ & $\begin{array}{l}\text { Financial management } \\
\text { (financing sources and } \\
\text { investment decisions). } \\
\text { Investment amount. } \\
\text { Monthly financing costs. }\end{array}$ \\
\hline Factor 3 & $\begin{array}{l}\text { Financial management } \\
\text { (financing sources and } \\
\text { investment decisions). } \\
\text { Investment amount. } \\
\text { Monthly financing costs. } \\
\text { How is the loan used? }\end{array}$ & $\begin{array}{l}\text { Financial management } \\
\text { (financing sources and } \\
\text { investment decisions). } \\
\text { Financing for the start-up. } \\
\text { Financing sources. }\end{array}$ & $\begin{array}{l}\text { Financial management (financing } \\
\text { sources and investment } \\
\text { decisions). } \\
\text { Financing for the start-up. } \\
\text { Financing sources. }\end{array}$ & $\begin{array}{l}\text { Financial management } \\
\text { (financing sources and } \\
\text { investment decisions). } \\
\text { Financing for business } \\
\text { opening. } \\
\text { Financing sources. }\end{array}$ \\
\hline Factor 4 & $\begin{array}{l}\text { Economic management } \\
\text { (recording and control). } \\
\text { How are the prices set? }\end{array}$ & $\begin{array}{l}\text { Economic management } \\
\text { (recording and control). } \\
\text { How are the prices set? }\end{array}$ & $\begin{array}{l}\text { Economic management } \\
\text { (recording and control). } \\
\text { How are the prices set? }\end{array}$ & $\begin{array}{l}\text { Economic management } \\
\text { (recording and control). } \\
\text { How are the prices set? }\end{array}$ \\
\hline
\end{tabular}


As a result of the methodology, the contribution of the factors to explaining the total variance in each of the sectors under analysis is obtained, as shown in Table 4. The results suggest that the four factors explain approximately $65.7 \%$ of the total variance for the manufacturing sector, $75.7 \%$ for the commerce sector, and $71.3 \%$ for the services sector. Factor 1 contributes the most to explaining the total variance, accounting for between one quarter and one third of it. The value for the fourth factor is very close to 1 , with it explaining $12.5 \%$ of the variance in manufacturing, $13.8 \%$ in commerce, and $12.4 \%$ in services. This explains why it is also included in the factorial structure.

Table 4

Factor contribution to total variance by sector

\begin{tabular}{lcccccc}
\hline \multirow{2}{*}{ Component } & \multicolumn{2}{c}{ Manufacturing } & \multicolumn{2}{c}{ Commerce } & \multicolumn{2}{c}{ Services } \\
\cline { 2 - 7 } & Total & PVE & Total & PVE & Total & PVE \\
\hline 1 & 1.994 & 24.928 & 2.179 & 31.126 & 2.308 & 28.844 \\
2 & 1.223 & 15.281 & 1.130 & 16.147 & 1.311 & 16.393 \\
3 & 1.043 & 13.037 & 1.027 & 14.676 & 1.093 & 13.668 \\
4 & 0.999 & 12.490 & 0.966 & 13.799 & 0.989 & 12.366 \\
\hline
\end{tabular}

The selection of factors to substitute the original variables was achieved through the factor analysis; these factors will be used in a regression model to determine the relationship between the variables and micro-enterprise performance. It should be noted that the variables representing economic and financial management factors might be different between the three economic sectors. The factors in Table 3, where factors are exhibited for each sector and the consolidated case, are labeled as either economic management (recording and control) or financial management (financing sources and investment decisions).

The economic management factor in the regressions related to the sectors and the consolidated regression groups the following variables: use of accounting records and issuing of sales receipts. This factor is labeled as recording and control, since the variables included are associated with the recording of financial transactions and controls, which are required by an adequate decision-making practice. This factor is very relevant to the manufacturing sector (as well as in the consolidated case) and is the second most important in commerce and services. Economic management also includes the factor associated with the variable how are the prices set, which is tagged as pricing, since it includes only that variable. This is the fourth most important factor in all sectors of the economy.

As for the financial management dimension, which exhibits the highest variability between sectors, the set of factors are labeled as financing sources and investment decisions. The behavior of the manufacturing sector is different from the other two, since it is more sensitive to a lack of accounting records or finance sources, while the commerce and services sector performance is highly affected by the amount and cost of loans. Consequently, financing sources are crucial for the former sector whereas loan conditions and their efficient application affect the commerce and service sectors more.

Finally, the results of the estimation of equation 7 using the corresponding factors in Table 3 are shown in Table 5. 
Table 5

Econometric results

\begin{tabular}{|c|c|c|c|c|}
\hline Results by sector & Manufacturing & Commerce & Services & Consolidated \\
\hline \multirow{2}{*}{ Constant } & $0.683^{*}$ & $0.516^{*}$ & $0.441^{*}$ & $0.559^{*}$ \\
\hline & $(0.0347)$ & $(0.0241)$ & $(0.0221)$ & $(0.0158)$ \\
\hline \multirow{2}{*}{ Factor 1} & $-0.406^{*}$ & $0.375^{*}$ & $0.111^{*}$ & $-0.270^{*}$ \\
\hline & $(0.0390)$ & $(0.0286)$ & $(0.0237)$ & $(0.0161)$ \\
\hline \multirow{2}{*}{ Factor 2} & -0.025 & $-0.198^{*}$ & $-0.235^{*}$ & $0.170^{*}$ \\
\hline & $(0.0330)$ & $(0.0269)$ & $(0.0220)$ & $(0.0160)$ \\
\hline \multirow{2}{*}{ Factor 3} & $0.219^{*}$ & 0.001 & $-0.074^{*}$ & -0.023 \\
\hline & $(0.0332)$ & $(0.0286)$ & $(0.0210)$ & $(0.0154)$ \\
\hline \multirow{2}{*}{ Factor 4} & 0.004 & 0.0034 & -0.004 & 0.007 \\
\hline & $(0.0317)$ & $(0.0025)$ & $(0.0209)$ & $(0.0158)$ \\
\hline \multirow{2}{*}{ Value of assets (capital) } & 0.016 & $0.087^{*}$ & $0.289^{*}$ & $0.213^{*}$ \\
\hline & $(0.0352)$ & $(0.0276)$ & $(0.0235)$ & $(0.0164)$ \\
\hline \multirow{2}{*}{ Man-hours (labor) } & $0.199^{*}$ & $0.057^{* *}$ & $0.146^{*}$ & $0.145^{*}$ \\
\hline & $(0.0369)$ & $(0.0285)$ & $(0.0219)$ & $(0.0161)$ \\
\hline \multirow{2}{*}{ Sex } & $0.142^{*}$ & $-0.184^{*}$ & $0.128^{*}$ & $-0.026^{* *}$ \\
\hline & $(0.0342)$ & $(0.0260)$ & $(0.0217)$ & $(0.0148)$ \\
\hline Adjusted $\mathbf{R}^{2}$ & 0.413 & 0.316 & 0.306 & 0.262 \\
\hline Estimation error & 5169.233 & 8740.583 & 7606.61 & 7985.539 \\
\hline
\end{tabular}

Source: Own elaboration with SPSS. Significance at the .01, .05, and .10 level are respectively denoted by *, **, and ***.The majority of the variables were relevant and statistically significant and are therefore suitable for inclusion in the regression analysis.

In general, the regressions exhibit appropriate statistics: the adjusted $\mathrm{R}^{2}$, indicating the ability of the independent variables of the model to explain micro-enterprise performance, falls between 0.26 and 0.42 ; most of the included independent variables turn out to be significant, suggesting that they are related to performance variations. Labor and capital, as measured by labor man-hours and the value of assets, are positive and mostly significant for the four regressions, as was expected, except for manufacturing, where the value of capital was not significant. This result may be the consequence of differences in the value of assets and income between sectors, which favors commerce and services more than manufacturing. Manufacturing in the sample is compounded by hand-crafted and traditional activities, requiring low capital. The control for sex is significant for all the regressions, suggesting that femalerun enterprises are different from those run by males, these differences being linked to the role of females in the household and their enterprises tending to complement household income, rather than being the main income source. However, this effect alternates in sign, suggesting that the differentiated effects of gender on performance across micro-enterprises depend on the sector. The consolidated regression indicates that the negative effect of gender is predominant. The regressions also indicate that the effects and the explanatory ability of the independent variables over the dependent variables vary across sectors, indicating important sector differences that may be the result of the specific contexts and sector dynamics.

The analysis of the factors associated with the economic and financial management for the manufacturing sector showed that factors 1 registry and control (-0.406) - and 3 - investment decisions (0.219) - are statistically significant, with 
the former being of greater importance to income. Factors 2 and 4 were not found to be significant. The negative relation of factor 1 , including use of accounting records and issuing of sales receipts, is surprising, and may be explained by the fact that these two economic controls are very simple and do not really provide information for improving the decision-making process or may not even be used by the entrepreneurs for those purposes. This is also the case for the commerce and service sectors.

In relation to the commerce sector, factor 1 , which is related to investment decisions such monthly financing cost, loan amounts, and how is the loan is used?, was positive and shows a higher impact (0.375) than factor 2, related to recording and control (-0.198), which indicates a negative relationship with monthly income. In the service sector, investment decisions (0.111) shows a positive relationship, while recording and control (-0.235), which has the highest impact, and financing sources (-0.074), had negative relationships with income. The consolidated analysis resulted in similar results: the statistically significant factors are recording and control (negative) and investment decisions (positive).

The economic management dimension proved to be negative and significant in all three economic sectors. On the other hand, the financial management dimension for commerce was significant and positive for the two factors (financing sources and investment decisions). With regard to the service sector, only financing sources were found to be negatively significant; the factor related to pricing was not significant in any case; investment decisions were found to positively affect business performance, while financing sources has a negative effect, except in the case of commerce.

These estimates show that economic management variables such as use of accounting records and issuing of sales receipts, grouped in the recording and control factor, were significant, although the relationship was negative. This outcome may be the result of the fact that, on average, $53 \%$ of the micro-enterprises do not keep accounting records, about $80 \%$ do not employ an accountant or bookkeeper, and only $25 \%$ submit a receipt of payment.

The estimation of the factors in the regressions allowed it to be verified that the economic management variables were significant i.e. the recording and economic control factors, which groups accounting records and the use or not of sales receipts, but the relationship was found to be negative. This result could be due to the behavior of these two variables specifically in manufacturing, commerce, and services, since between $44 \%$ and $62 \%$ of these types of enterprises do not keep accounting records, around 20\% employ an accountant or professional, and between $2 \%$ and $7 \%$ use the cash register provided by the Tax Authority. Regarding the use or not of sales receipts, approximately $75 \%$ of the enterprises do not issue any type of sales voucher.

Aguilar et al. (2007) concluded that keeping accounting records and controls over inventory, along with other management practices, affect the ability to plan purchases and facilitate access to external financing sources. Thus, insufficiencies in the economic management practice contribute to the poor performance of micro-enterprises in all sectors. The financing sources had a negative effect and were significant only in the service sector. The positive and significant coefficient for investment decisions may be explained by the fact that real finance requirements and the availability of funds should increase profits.

Financial management activities are not only about the search for external financing sources, but also about the financing amount and cost. These decisions must be consistent with the size, type of business, and profitability. The enterprises under study seem to be aware of this condition, because the cost of funding is covered by most of them. However, there is a clear negative relationship between financing sources in the service sector and profits. Financing for business start-ups, as was noted above, typically 
comes from the entrepreneur's personal savings; therefore, the investment tends to be insufficient to produce the expected earnings expansion so as to achieve the productive potential suggested by scale or even by the market segment.

Finally, the service sector is found to be favored by commercial banks and lenders, who charge significant interest rates, but at the same time this sector received less financing from government and credit unions. Usually, funds from government programs are granted under soft conditions or may even be non-refundable. The interest rates of banks and lenders tend to be high for micro-enterprises, thus hindering profits. These facts contribute to explaining the negative effect of financing sources over performance.

\section{Conclusions}

Based on the widespread interest in research to understand micro-enterprise performance, the aim of this paper was to characterize the economic and financial management in Mexican micro-enterprises and measure their impact on performance. The paper provides evidence and explanations to enrich the understanding of the operational problems faced by Mexican microenterprises, which may also be useful for similar micro-enterprises in other developing countries.

It is concluded, first, that economic and financial management practices are carried out in Mexican micro-enterprises. Even though they face many problems and limitations, the micro-enterprises include some activities that depict economic and financial efforts in their management, e.g. basic accounting, bookkeeping, economic checks and controls, and investment and financing decisions, regardless of the smallscale business activity. This allows the hypothesis regarding the relationship between economic and financial management practices in microenterprises and their performance to be accepted.

Second, the data analysis contributed to identifying some characteristics of microenterprises in Mexico, e.g. they operate informally, exhibit low managerial experience, use basic accounting and inventory management practices, and receive some banking finance, though most of their investments are financed with personal savings and informal loans. In addition, the micro-enterprises set prices mainly by adding a mark-up over costs, but also in accordance with competitors, and they tend to invest mainly in fixed assets as a way to improve their businesses and make decisions to obtain the necessary financing for business permanence.

However, the way in which microenterprises manage their businesses economically is negatively affecting their performance, in the sense that they are not achieving their potential. The practices used to carry out their economic controls and records had a negative relationship with performance variables in the three economic sectors under analysis. However, financial management practices had a positive and usually statistically significant relationship with enterprise performance. Therefore, government support programs and public policies promoting small businesses must take into account entrepreneurs' training not only to acquire suitable management and control practices, but also in developing skills to analyze their records for decision-making. This should help business owners to create stronger and more profitable micro-enterprises and to deal with liquidity problems.

This research exhibits some limitations that condition the paper's findings and present challenges for future research. Data on microenterprises is scarce. The data used in this paper was taken from a multipurpose, cross-sectional survey. Only a few variables could be used to describe the economic and financial management of the enterprises that could be validated from the standpoint of the theory. Also, the data cannot be analyzed over time, given the survey sampling methodology. Thus, further research regarding the financial and economic management in enterprises of this type could benefit from exclusive surveys focusing on this topic. This would be part of a future research agenda. As for the paper's findings, they are useful for guiding 
training programs focused on micro-enterprise owners in developing countries and for enriching the stock of literature on micro-enterprises, which may support further research.

\section{References}

Acs, Z., \& Amorós, J. E. (2008). Entrepreneurship and competitiveness dynamics in Latina America. Small Business Economics, 31(3), 305-22.

Aguilar, J. G.; Ramírez, N., \& Barrón, K. (2007). Conformación de la microempresa marginada en la frontera norte de México. Estudios Fronterizos, 8(15), 51-71.

Anzola, S. (2002). Administración de pequeñas empresas. (2nd ed.). Mexico City: McGRAWHILL Interamericana de México.

Benett, N., Ketchen, D., \& Shultz, E. (1998). An examination of factors associated with the integration of human. Human Resource Management, 37(1), 3-16.

Brealey, R.; Myers, S., \& Allen, F. (2008). Principles of Corporate Finance (9th ed.). McGraw Hill-Irwin. New York.

Correa, J., \& Jaramillo, F. (2007). Una aproximación metodológica y prospectiva a la gestión financiera en las pequeñas empresas. Contaduria Universidad de Antioquia, Colombia, 50, 93-118.

Drucker, Peter (1973). Management: Tasks, Responsibilities, Practices. New York: Harper \& Row, Publishers.

Escobar, G.; Arias, L., \& Portilla, L. (2009). Modelo para medir la situación Financiera en Empresas Pyme. Scientia Et Technica, XV(43), 273-278.

Gitman, L., \& Zutter, C. (2012). Principles of Managerial Finance (13th ed). Boston: Pearson Education Inc.
Hill, C., \& Jones, G. (2005). Administración estratégica: Un enfoque integrado. México: McGraw-Hill.

Hitt, M., Ireland, D., \& Hoskisson, R. (2008). Administración estratégica: Competitividad y globalización, conceptos y casos. México: Thompson.

INEGI (2012). Encuesta Nacional de Micronegocios, ENAMIN. México: Instituto Nacional de Estadística y Geografía.

León, J., \& Schreiner, M. (1998). Financiamiento para las micro y pequeñas empresas: Algunas líneas de acción. Revista Economía, 21(41), 1-60.

Mariño, G., \& Medina, I. (2009). La administración financiera: Una utopía en las microempresas. Criterio Libre, 7(11), 123-144.

Méndez, C., \& Rondón, M. (2012). Introducción al análisis factorial exploratorio. Revista Colombiana de Psiquiatría, 41(1), 197-207.

Mungaray, A., \& Ramírez-Urquidy, M. (2000). Impacto de la restricción monetaria en pequeñas empresas de Baja California. El Mercado de Valores, 6O(10), 67-72.

Mungaray, A.; Ocegueda, J. M.; Ledezma, D.; Ramírez, N.; Ramírez, M., \& Alcalá, C. (2007). Formación por medio del servicio: Un modelo de servicio social universitario en apoyo a microempresas marginadas. El Trimestre Económico, 74(296), 987-1011.

Mungaray, A., \& Ramirez-Urquidy, M. (2011). Full and part-time entrepreneurship and the supply of entrepreneurial effort: Evidence from Mexican microenterprises. Journal of Developmental Entrepreneurship, 16(04), 441-458.

O’Neill, P.; Sohal, A., \& Teng, C. W. (2016). Quality management approaches and their impact on firms' financial performance An Australian study. International Journal of 
Production Economics, 171(P3), 381-393.

Paramasivan, C., \& Subramanian, T. (2009). Financial management. New Delhi: New Age International Limited, Publishers.

Pollack, J., \& Adler, D. (2016). Skills that improve profitability: The relationship between project management, IT skills, and small to medium enterprise profitability. International Journal of Project Management, 34(5), 831-838.

Porter, M. (1980). Strategy competitive. New York: Free Press.

Quinn, R. E., \& Rohrbaugh, J. (1983). A spatial model of effectiveness criteria: Towards a competing values approach to organizational analysis. Management Science, 29, 363-377.

Ramírez, M.; Mungaray, A., \& Guzmán, N. (2009). Restricciones de liquidez en microempresas y la importancia del financiamiento informal en Baja California. Región y Sociedad, XXI(44), 72-90.

RED PYMES-CUMEX (2010). Un estudio comparativo del perfil financiero y administrativo de las pequeñas empresas en México: Entidades del Estado de México, Hidalgo, Puebla, Sonora y
Tamaulipas. Resultados finales. Revista del Centro de Investigación, Universidad La Salle, 9(33), 5-30.

Rodríguez, J. (2010). Administración de pequeñasy medianas empresas (6th ed.) Mexico City: Cengage Learning.

Sierra, M., \& Madriz, D. (2012). Estrategias para la adecuación teórica del proceso planificador en las microempresas manufactureras del estado Táchira. Ingeniería Industrial: Actualidad y Nuevas Tendencias, 3(8), 21-38.

Stoner, J. A. F., Freeman, R. E., \& Gilbert, D. R. (1996). Administración. México: Pearson educación.

Velásquez, A. (2003). Modelo de gestión de operaciones para pymes innovadoras. Revista Escuela de Administración de Negocios, 47(JanApr), 66-87.

Vera-Colina, M. (2011). Metodología para el análisis de la gestión financiera en Pymes. Colombia: Facultad de Ciencias Económicas. Escuela de Administración y Contaduría Pública Universidad Nacional de Colombia. Retrieved from www. econfinanzas.com/finanzas/modulo.pdf. 


\section{APPENDIX 1 - NATIONAL OCCUPATION AND EMPLOYMENT SURVEY}

\section{National Micro Business Survey \\ ENAMIN 2012 \\ (Extract)}

\section{RECORDS AND ACCOUNTING}

36. Does your business or activity have registration before a notary? (Listen and circulate the indicated option)

1 Yes

2 No

37. In this activity or business ... (Read the options and the indicated one circulates)

1 Do you go to the services of an accountant or professional to keep accounts?

2 Do you only use a notebook or a personal notepad to keep accounts?

3 Do you use the cash register of the Ministry of Finance?

4 Does not have any accounting records

5 Refused to answer

38. What type of sales receipts are issued to your customers? (Read the options and the indicated one circulates)

1 Invoices

2 Only notes or sales receipts

3 None

4 Refused to answer

\section{DETERMINATION OF PRICES}

48. Normally, how do you fix the price of your goods or services? (Read the options and the indicated one circulates)

1 Sets the prices in relation to the competition

2 Take official or supplier prices

3 By haggling

4 Depending on the client

5 Add a fee or percentage to the cost

6 Other form Specify

7 Refused to answer 


\section{TIME DEDICATED TO BUSINESS}

52. Regardless of what you have just told me, how many hours do you usually dedicate to the following activities per week? (Read the options, circulate the indicated ones and record the hours)

1 Manage your business

2 Buy raw materials or products

3 Prepare or elaborate products

4 Attending, visiting or charging products and / or services to its clients

5 Repair, maintain or buy machinery, equipment or vehicles

6 Carry out business procedures

7 Cleaning the business or workplace

8 Other activities Specify

0 Exclusive interviewer

\section{EQUIPMENT AND EXPENSES}

56. During 2012, in your business or activity, how much did you invest in the purchase or acquisition of

... (Read the options, circulate the indicated ones and enter in pesos the amount invested)

1 tools and work tools?

2 machinery?

3 furniture and equipment?

4 terrain or local?

5 vehicles?

6 other assets

7 He did not invest

8 Refused to answer

9 Exclusive interviewer

57. If you had to sell the tools, utensils, machinery, furniture, equipment, land, premises and vehicles of your property that you use in your business or activity, how much would you sell them? (Listen and circulate the indicated option and in your case write down the amount in pesos)

$\$ 1$

2 It has no assets

3 The assets with which they have no commercial value

4 They are borrowed

5 Refused to answer

6 Do not know

69. On average, how much does your business or activity leave you per month? (Listen, circulate the indicated option and write down the amount when appropriate)

$\$ 1$

2 The business is beginning and still does not generate profits

3 Refused to answer 


\section{FINANCING}

80. The money to start this business or activity, where did it mainly come from? (Listen, write down the answer and then classify it in the indicated option, if the informant says it is a government program, ask for the name)

1 Commercial banking (BBVA-Bancomer, Banamex, etc.)

2 Development Banking (Nafin, Bancomext)

3 Government Program

4 Popular boxes

5 Credit of suppliers

6 Private lenders (with interests)

7 Loan from friends or relatives (without interest)

8 Sale, mortgage or pawn of your goods

9 Liquidation of previous employment

10 Personal savings

11 Another source

$12 \mathrm{He}$ inherited the business

13 He did not need it

83. To whom did you apply for the most recent loan? (Listen, write down the answer and then classify it in the indicated option, if the informant says it is a government program, ask for the name)

1 Commercial banking (BBVA-Bancomer, Banamex, etc.)

2 Development Banking (Nafin, Bancomext)

3 Government program

4 Popular boxes

5 Credits from suppliers

6 Private lenders (with interests)

7 Loan from friends or relatives (without interest)

8 Other

86. How much was the loan amount? (Listen and write down the amount indicated)

$\$$

89. What did you mainly use this loan for? (Listen, write down the answer and then classify it in the indicated option)

1 Buy local or vehicle

2 Expand, adapt or repair the premises or vehicle

3 Acquire or buy merchandise

4 Pay business debts

5 Buy machinery, equipment or tools

6 Repair or maintain machinery, equipment or tools

7 Other

8 Refused to answer 
About the Authors:

1. Martín A. Ramírez-Urquidy, PhD in Economics, Universidad Autónoma de Baja California, Mexicali, México. E-mail: martinramirez@uabc.edu.mx

ORCID

(iD) 0000-0003-0571-0477

2. José G. Aguilar-Barceló, PhD in Economics, Universidad Autónoma de Baja California, Tijuana, México. E-mail: gaba@uabc.edu.mx

ORCID

(iD) 0000-0002-6378-6886

3. Malena Portal-Boza, PhD in Economics, Universidad Autónoma de Baja California, Tijuana, México. E-mail: mportal@uabc.edu.mx

ORCID

(iD) 0000-0002-4237-1534

\section{Contribution of each author:}

\begin{tabular}{|c|c|c|c|}
\hline Contribution & $\begin{array}{l}\text { Martín Ramírez- } \\
\text { Urquidy }\end{array}$ & $\begin{array}{l}\text { José Gabriel } \\
\text { Aguilar Barceló }\end{array}$ & $\begin{array}{l}\text { Malena Portal } \\
\text { Boza }\end{array}$ \\
\hline 1. Definition of research problem & $\sqrt{ }$ & & $\sqrt{ }$ \\
\hline $\begin{array}{l}\text { 2. Development of hypotheses or research questions (empirical } \\
\text { studies) }\end{array}$ & $\sqrt{ }$ & & $\sqrt{ }$ \\
\hline $\begin{array}{l}\text { 3. Development of theoretical propositions } \\
\text { (theoretical work) }\end{array}$ & & $\sqrt{ }$ & $\sqrt{ }$ \\
\hline 4. Theoretical foundation/Literature review & & $\sqrt{ }$ & $\sqrt{ }$ \\
\hline 5. Definition of methodological procedures & $\sqrt{ }$ & & $\sqrt{ }$ \\
\hline 6. Data collection & & & $\sqrt{ }$ \\
\hline 7. Statistical analysis & & & $\sqrt{ }$ \\
\hline 8. Analysis and interpretation of data & $\sqrt{ }$ & $\sqrt{ }$ & $\sqrt{ }$ \\
\hline 9. Critical revision of the manuscript & $\sqrt{ }$ & $\sqrt{ }$ & \\
\hline 10. Manuscript writing & $\sqrt{ }$ & $\sqrt{ }$ & $\sqrt{ }$ \\
\hline 11. English version revision and interpretation & $\sqrt{ }$ & $\sqrt{ }$ & \\
\hline 12. Overall editorial revision & & $\sqrt{ }$ & \\
\hline 13. General coordination of revision & & $\sqrt{ }$ & \\
\hline
\end{tabular}

